\title{
But What if the Shoes were Dancing? Learning to Dance, Dancing to Learn
}

\author{
Andy Curtis
}

\section{From Student-teacher to Teacher-student}

A long-established feature of many initial language teacher education programs is exposure to target language teaching, as described by language teacher educators like Diane Larsen-Freeman (1983) in the United States and Gary Birch (1992) in Australia. For my early TESL (Teaching English as a Second Language) qualifications, our group, all native speakers of English, were required to attend 20, one-hour lessons of beginner's Chinese. As none of us knew any Chinese, and all of the teaching was in the target language, Chinese, this gave us a chance to experience what our learners might think and feel when we tried to teach them entirely in the language they were trying to learn, English. In a later course, the same was done, but this time with the language of Iceland.

We each kept a journal, or learning log, of what we were learning about language teaching and about what it felt like to be language learners completely immersed in a language we (initially) knew nothing about but were trying to learn. Although we did comment on the meaning, structure, and pronunciation of the two languages, and made (frequently incorrect) assumptions about our second languages based on what we (thought) we knew about our first, how much or how well we learned Mandarin Chinese or Icelandic was not the point. Thinking and feeling about language and learning, becoming sympathetic and empathetic reflective teachers through being reflective learners, were some of the main aims (see also Lowe, 1987).

This technique has not only been used for language teachers in training, but experienced language teachers too. Kathi Bailey (Bailey, Curtis \& Nunan, 2001, pp. 97-98) describes how she taught a 30-minute language lesson using only Korean to a group of teachers of English in Brazil who had strong - but markedly different - feelings about use of students' first language (L1, in their case, Portuguese) in second language (L2, in their case, English) classrooms. After this brief but unexpected "shock language lesson", Bailey was "amazed" to find that some of the teachers who were originally most adamant about prohibiting the use of students' L1 in their L2 classrooms, were "among those most frustrated and intimidated by the experience of being restricted to the target language" ( $\mathrm{p}$. 97).

A third variation, and another level of reflectivity, is where experienced language teachers choose to enroll in language learning courses. In Lessons Learned from Being a Student Again, Laura Latulippe (1999) explains that after 25 years as an ESL teacher, she wanted to remind herself of what it felt like to be a language learner again. She admits that the role reversal was more difficult than she thought it would be, partly because of the loss of self-esteem she experienced, which she deals with using many strategies, 
including ironic humor: "After a few days, I am embarrassed to tell anyone my profession" (p. 106).

Joachim Appel (1995) kept a teaching diary for six years, documenting his experiences as a secondary school EFL teacher in Germany. Many of his entries describe the interaction between he and his students as they and he changed, grew and developed. However, some of his entries describe his experiences as a language student in Italian and Chinese courses. His accounts illustrate, among many other things, how different the language classroom looks from where the students sit (pp. 68-69).

According to Bailey, Curtis and Nunan (2001) "the experience of putting yourself in the learner's shoes can be incredibly illuminating (and sometimes even humbling)" (p. 96). But what if the shoes were dancing? (as some had been in Dennis Sumara's 1999 article in this journal). All of the above examples come from beginning or experienced language teachers being put or putting themselves in the role of language learners. This is helpful as the role(s) maybe different but the objective is the same, i.e., to find out more about teaching and learning languages. But what if an experienced language teacher and teacher educator put themselves back in the role of a student, by studying a subject or learning a skill completely new to them?

A language teacher draws upon, indeed cannot help but draw upon, linguistic and pedagogical frames of reference in making sense of what he is experiencing in his role(s) as a language learner. These frameworks may act as enhancing filters, sharpening the images, but they may also create distortions or distractions caused by our linguistic and pedagogical knowledge. But what if all of our academic qualifications, our reading and research writing were of no obvious or apparent use to us in learning this new skill? Whether we would gain more or less from the experience is an academic question, but it is likely that the experience would be palpably different.

\section{The Course and the Journal}

The relationships between music and language have long been recognized, perhaps especially in the case of tonal languages, such as Chinese. In Jazz, Toni Morrison eloquently portrays how musical instruments and the human voice can bitter-sweetly intermingle: "Below is shadow where any blasé thing takes place: clarinets and lovemaking, fists and the voices of sorrowful women" (1993, p. 7). But, to the best of my knowledge, relationships between teaching/learning language and teaching/learning dance are few and far between, which was one of the things that interested me about taking a beginners dance class.

The course I and my partner (referred to as ' $L$ ' in this piece) enrolled was an adult, evening class at the nearby university where she worked (and I played). The course ran for five Sunday evenings, from 5 November to 3 December 2000, for 90 minutes each evening, from 6.30 p.m.-8:00 p.m. Including ourselves, eight couples were enrolled in the course, hoping to, according to the course description: 
Learn how to do the Fox Trot, English and Viennese Waltz, Tango, Rumba and the Cha Cha. No previous experience necessary for beginner classes. Designed for couples.

Register with your own partner or we can try and pair you up. $(2000$, p. 17)

The course fee was around $\$ 35.00$ (Canadian) each, which were paying at the physical education centre's office, when I saw the following sign taped up on some filing cabinets inside the office:

Work like you don't need the money

Love like you've never been hurt before

Dance like no one is watching

Apart from it being very good advice, I also took this to be a good omen.

Much has been written on and in language teachers' journals, such as Vivian Paley's (1997) reflections of her experiences as a kindergarten teacher, in which she writes:

There are few novelists among us, and only a small number will have their work published in any form. But we all have the desire to learn more about ourselves and the children who call us Teacher. My way has been to resurrect the daily journal to help me study the most complex society ever assembled in a single place: the school classroom (p.122)

One common problem with teachers' keeping journal entries is that teachers are very busy people but keeping a journal takes time, and Gillian Palmer (1992) suggests making entries on alternate days or on a weekly basis (p. 243). The importance of regularity is highlighted by Shelley Wong (1994), who feels she "cannot overemphasize the importance of setting and sticking to a minimum weekly writing goal for yourself" ( $p$. 13). However, my entries for the dance course were quite irregular, in which case I wondered if my 'dance class diary' would still be as useful a vehicle for reflecting on learning and teaching. Questions of time and timing, quantity and quality - of how much time teachers have to spend on entries, when they can/should make them and how much we can write - have interested me ever since I started keeping teaching journals myself, some years ago now.

My entries were written somewhat haphazardly, from quick points listed one week after class, to brief continuous prose writing right after class, to longer prose entries made between a couple of days and up to one week after a lesson, plus a few hurried notes made just before some lessons. The time spent on writing the entries was generally between 10 and 20 minutes, but up to half an hour, with the five main entries being anywhere between around 300 and 700 words. I wondered whether such entries would still be of use, and if so, in what way(s)?

Extracts from the main entries have been selected for this paper, partly for reasons of length but also privacy. As a language teacher educator, my entries were written with an awareness that they may lead to a public piece, to be read by strangers; reviewers, editors 
and other members of our academic community. They were, however, written primarily for me to be able to articulate my thoughts through the act of writing, and for me to have some personal and private record of this learning experience. Apart from some small changes, the entries are presented here as they were written originally. For example, nonstandard and idiolectal abbreviations used in the journal are given in full here, e.g., 'fave diff' in the second entry is given in full as 'favorite difference' here. Some spelling, grammar and punctuation have been tidied up, but only if the intended meaning is made unclear by a non-standard use of the language.

\section{Writing, (Re)Reading and Reflecting}

The first entry was written on Sunday November $11^{\text {th }}, 2000$; one week after the first lesson and shortly before the second. It was written in ten minutes and in the form of 15 statements (around 400 words in total). Apart from making the statements into bullet points, the statements are presented here as they were originally entered into my journal. Here are the first four:

- Our uncertainty, nervousness from the outset.

- Not being able to find the right room, scurrying up and down hospital-like staircases

- Wondering who the other students would be, and expecting that they'd be older couples (but they seem to be students at the University and we seemed to be the oldest!).

- Our teacher: What would she look like and be like?

What these points showed me, on rereading them more than two months after they were first written, is that one of the benefits of being an ab initio beginner again is that reexperiencing of the anxieties just before beginning a new course. As well as experiencing some of the very practical problems of being a new student, like knowing where to go on your first day. It is interesting to see how concerns about physical appearance - of ourselves, the other students and the teacher - manifest themselves early in this extract and elsewhere in this first entry, as well as in the brief notes made just before the second lesson.

On an intellectual, cognitive, head level, I know that to respond based on physical appearance is wrong, and that First Impressions are frequently misleading. However, on an emotional, affective, heart level, I am reminded here that physical appearance and first impressions are all we have to go on initially and may be inescapable. Being reminded of this is especially important for me, as a non-North American teacher of color and teacher of English living and working in North America, who has sometimes struggled to deal with reactions and responses to me based on just these kinds of physical, first impressions. This point has been brought home to me even more so over the last five months, as a brown-skinned person, starting to live and work in small town America just before September $11^{\text {th }} 2001$. In spite of such experiences, and although I am trying to focus on myself and my responses in this strange, new situation in which I find myself, I am still a teacher, and so cannot help noticing and noting things about our teacher, such as: 
- Her initial frustration, which she admit to us, because of the music system not being set up, and the store cupboard with it in being blocked.

- Her asking “did I introduce myself" which she hadn't, so she did so.

- Her telling us how many years she and her husband have been dancers/dancing.

These second three points from the first entry show one teacher observing another, and it is possible that a student from somewhere other than teacher education would not note these points. Even though the subject matter is new to me, this does not stop me from seeing the ways in which our teacher starts to create relationships with us, her students. It is likely that these kinds of observations are a reflection of what $I$ try to do when $I$ meet a new group of students, i.e., start to form bonds with the students and establish credibility by talking about my background and teaching experience. In fact, this became an important part of my introduction to students (and staff) in Hong Kong, for most of whom, a teacher of English was an elderly, white, British person. This led the students (and teachers) to be concerned about my ability to teach them what they assumed was for me the same as it was for them (i.e., English as a second or foreign language).

What is most interesting here is how I think I am writing about the teacher I am observing, but on re-reading the entry (months later), I realize I am, in fact, writing at least as much about my own teaching. I have called this 'second order' or 'secondary' reflective practice, seeing our professional-personal selves more clearly through seeing others'; through being in the presence of other teachers whilst we ourselves are primarily in the role of learners. This may also be called 'refractive practice', as refraction refers to the physical property of light (sound and other waves), which changes direction when it passes from medium to another, in this case the teacher being the medium through which the waves of experience pass.

An image of our professional selves is projected onto another teacher teaching and then reflected back at us, enabling us to see our selves more clearly though them. This distancing has been referred to by Leo van Lier (1988) as 'estrangement', which I have elaborated on (1999), and referred to as a way of 'seeing more by being further away'.

As the image of their teaching is presented to us, as teacher-students, we initially see the teacher before us. But on looking deeper, and perhaps more clearly from the distance created by the time between writing our journal entries and (re)reading them, we see our selves.

Comparing the first and second journal entries, comments about the personal appearance of ourselves, the teacher or other students are noticeably absent, with the focus appearing to shift to group dynamics, perhaps as a result of less initial anxiety after week one:

With the group being so small, L and I and one other couple appear to be the only two who don't know the other couples, most of whom seem to know at least one other couple from the start, or maybe they're just more out-going.

The teacher-student journal entries of both Laura Latulippe and Joachim Appel, referred to above, highlight the need for the students' efforts to be recognized, both 'privately', 
teacher-to-student, and 'publicly', in front of the rest of the students by the teacher. This need is described as "sad and sorry" in the last part of this entry, but again, it reminds me of how important and deep-seated this need is:

I did my [Latin dance] wiggle-hips thing with Teacher in front of the group, as she chose me to do a little demo with, and I couldn't help being so pleased when she drew the group's attention to my well-executed hip movements, albeit in a light-hearted way. Oh, our sad and sorry need for public praise!

The entry about the third lesson $\left(19^{\text {th }}\right.$ November, 2000) was longer than the first two, and written two days after the lesson $\left(21^{\text {st }}\right.$ November, 2000). Here is the first part of that entry:

This is the first [dance] lesson that I've actually looked forward to, which may be because we did some practice this week. Tho' only a few 20 min sessions, and those with a CD of Chinese music...it did seem to help.

This extract reminds me that practice not only helps with skills development, but that students, apparently myself included, take time to settle into a new course. Another point of advice which I give to my language students, and which I'm pleased to see that I am following here is the 'little and often' approach (i.e., telling them that practice for 20 minutes each day is better than one hour every three days).

The effect of the short but personal anecdote was demonstrated succinctly in this third lesson, when our teacher:

stopped the music so she could tell us how 'refreshing' it was to see us 'young people' learning and doing these dances, as the other evening she was at one of her dance evenings with her husband and noticed how old everybody was there. She said it made her very happy....to see us young 'uns going at it.

This story telling did not appear to be part of our teacher's lesson plan, but more of an afterthought, and perhaps all the more engaging for that. It was not a 'deep disclosure' revealing anything very personal, but it did come across as a gentle and caring way of both recognizing our inexperience but also our potential and 'youthful' energy. I see now that this is part of the message that I try to get across to my own beginner level ESL/EFL students; that I recognize they are early on in a long, linguistic journey, but that they have great potential. It is also possible that I too use such stories to make such points, though I am not sure. But I will be more aware of doing this, if I do, in future, and do it more consciously and deliberately than before, having seen the benefits of doing this.

The group dynamics were mentioned in the second entry, and are not(ic)ed again here; this time with reference to one way that learners can use humor to create a shared experience and a relaxed atmosphere which helps them to deal with their anxieties and to focus on their learning:

I guess the best time must be in the middle [of the lesson], when we've relaxed into it a bit more, we've all laughed - which we do quite a bit, much of it little, nervous self- 
conscious laughs, but they do help - and we're now focusing on the steps and forgetting about the time.

This last part of the entry also reminds me of the importance of allowing adequate "warm up' and 'cool down' time at the beginning and end of my lessons, and not to forgo these because of my own concerns to cover as much material as possible, as quickly as possibly.

The entry for the fourth class was also written just after the lesson $\left(26^{\text {th }}\right.$ November, 2000). Like the last lesson, this one started with what appeared to be an unplanned story telling, but of a different kind, when our teacher decided to:

open/start with a lovely anecdote: personal, recent and relevant. We were going to start with the Waltz, which was, she felt, the most important of dances. She told us about her daughter's wedding, yesterday, and about her trying to show/teach her son or son-in-law the waltz...but he was lost. Afterwards, he said/admitted, I think to the assembled familyfriend masses, that he was the only one who hadn't gone to the dance lessons.

In this lesson we were treated to a privileged glimpse of a private and a significant family event, making its impact greater than the previous disclosure. It felt good to know that she was willing to share these moments with us. I too perhaps do this to help create some kind of bond between teacher and students, whilst maintaining a safe and comfortable distance. Like being ready to dance close(r) together, but not yet cheek-to-cheek.

The relationships and analogy between the rhythms of language and the rhythms of dance were referred to in the entry for the previous lesson, but they are extended and expanded upon here, the following week:

Lots of language learning analogies came to me today. Like how much better I did when $\mathrm{L}$ and I practiced out of class with each other, compared with how I/we did at the start of the lesson. Like how much more difficult it was to do it [the moves] with so many other people (in a class) trying to do it at the same time, and it seeming like most of us were doing completely different things! The timing and rhythm take time to pick up, and again, if you and your interactional partner are moving to different rhythms, you collide into others, as we nearly did a few times tonight (tho' not seriously), as well as into each other.

Although these analogies might constitute 'negative associations', as they focus on problems, they are nonetheless useful in helping me as a language teacher become more aware of, and reminded of, important differences between the classroom and the home. We humanist teachers would like to see our classrooms as safe and secure places compared to the 'outside world'; places where our learners can and should make mistakes and take risks without fear, which may not be the case 'outside'. But for me this entry also shows some of the limitations of the classroom and some of the benefits of learning away from school. 
As teachers, we are well aware of how tiring and demanding teaching can be, even when it is enjoyable and creative, but a point made towards the end of this entry reminds me of how much is required of the learners:

You see these guys, like the guys on [the Japanese film] Shall We Dance - tho' after a lot of blood, sweat and tears (and years) - making it [dancing] look easy and graceful, but you don't realize how tiring and demanding it can be, both physically and mentally.

Being able to sympathize with our learners' tiredness - physical, intellectual and emotional - is very helpful for both parties. Being able to empathize is even better, and perhaps better still is to for us to have first-hand, regular and recent experience of the demands of learning, even if the course is something the learners have self-selected to do and do it for pleasure, as we did. How much more demanding, then, must it be for some of our students on required or compulsory courses, who are not in our class out of choice and who are not there for the fun of it?

The entry for the last lesson was made on December $11^{\text {th }}, 2000$; just over one week after the fifth and final lesson (on the $3^{\text {rd }}$ ). It was the longest of the entries, both in terms of time spent writing and length.

After commenting on the relatively long time between the lesson and my journal entry, and the fact that even though we had by then two CDs of ballroom dancing music, we had, again, not done any practice, I go on to say:

I don't think it's apathy or laziness, at least they're not the major reasons [for not practicing], I think. Maybe it's more to do with feeling that we now know the basics, at least of the dances we've been taught so far, so there's less/little incentive to practice.

These few lines bring back memories of the work I've studied over the years on language learning and student motivation, in particular that fact that 'students learn if they see a reason to learn,' and the different kinds of motivation: instrumental - learning the language for a specific reason (e.g., for business), and integrative motivation - learning it for pleasure. A number of the other students appeared to be at the dance classes for a specific purpose, namely, to prepare for up-coming Christmas balls and dances. Our motivation was more integrative, which I have tended to think of as being in some ways 'better'; learning for the joy of learning rather than with a particular end in mind/sight. But maybe those students with more instrumental motivation practiced more than we did! This delicate balance seems so hard to find and maintain - between having clears aims, objectives, and goals, but without these being in any way constraining or detracting from the enjoyment of learning.

In the journal entry on the second lesson, I acknowledge our or my "sad and sorry need for public praise!" (see above), which comes up again here, though not described in quite such harsh or negative terms, and this time in relation to two opposite pairs: processproduct and practice-preach, both of which are related, in different ways, to how we teach and learn: 
My polka was pretty good. By which I mean, when she [our teacher] used me to demonstrate, it went well and she praised me to the rest of the group. Ah, that need to for teacher approval! So much for our pushing 'process not product' but then needing a mark - a good mark - on our own final test papers, or some other visible form of validation!

In the last lesson, we discovered that our teacher's first language was Czech. This seemed to me an exciting discovery, but reflecting on my reaction, I wrote in my journal, "I wonder why that matters to me, to know that" followed by my answer:

Is it that all students are more interested in their teachers as people, rather than "just" as teachers? Or maybe it's like the film stars, if you'll forgive the comparison! We need these larger-than-life figures, but we also crave details of their lives, especially the parts where they mess up, which shows us they're just like us in most ways. Perhaps we want it all, the professional persona and the private details.

Of all of the definitions of teaching I have come across, those that mean most to me are definitions based on the notion that teaching and learning are based on the formation of relationships (Curtis, 1999), some of which are more obvious than others. For example, the relationships formed between text and task, task and test, attitudes and behaviors, and curriculum, syllabus and classroom activities. But perhaps the most important teaching relationships are those created, conveyed and communicated, through the language interactions, between ourselves and our learners. In addition to the process-product and practice-preach distinction, a third, alliterative double-p distinction can be added. As these journal entries and my re-reading of them shows, one other perhaps less obvious but fundamental relationship is that between our personal and professional selves.

I wondered initially whether such brief periods of writing, such short and haphazardly made entries, would be of use to me in my professional development as a language teacher. Having re-read the entries and written about my responses to them, it is clear to me that perhaps all learning experiences, recorded in whatever way we can, may move us to deeper levels of reflection.

\section{Significance}

It is important at this point to consider the potential significance of this paper for language and literacy educators, researchers and practitioners.

From a research perspective, this paper shows that journal entries, even those not kept systematically, even those kept somewhat haphazardly, can still act as a source of stimulated recall data (Nunan, 1994), which has been used more commonly to gather data from students (Woods, 1989), but which has great potential for enabling us to learn more about what is, and is not, happening in our classrooms, from teachers' perspectives. In terms of developing frameworks of understanding, the paper expands the notion of reflective practice by adding a 'refractive' aspect. I have heard language and literacy teachers in many countries explain that, for a variety of reasons, they are not able to engage in research and on-going professional development. This paper is an example of combining the two, using journal entries as a way articulating teaching and learning 
experiences, as a way of recording these experiences, and as a source of introspective data (Bailey, 1991).

In addition to extending the reflective metaphor, this idea of 'refractive practice' may help us, in our professional development through observation of other teachers, become more aware of the relationship between what we see happening outside of ourselves and what is happening within us, as a result of what we are seeing. Journal entry data is sometimes seen as being 'too subjective' according to more traditional research paradigms. However, it is possible that re-reading our entries some time after they were written may in fact give us a kind of 'objectivity', as a result of the distance created by the time and space between our teaching and learning experiences, our writing about them, and our re-readings of those accounts.

Also from a practitioner point of view, many of us, as language and literacy teachers, frequently ask our students to keep journals, but how many of us do so regularly? In my experience, far more of us do the former than the latter. How many of us really put ourselves in the place and position of our learners, especially our true beginners?

Relatively few it seems. There are many good reasons for this, the main one being lack of time for many teachers, but this paper shows that if we can make time for such activities, they may help us in being the sympathetic and empathetic reflective teachers we desire to be. Seeing how different our classrooms look and feel from where our learners sit, reexperiencing the initial concerns and anxieties when starting a new course, discovering new metaphors which enable new ways of understanding the highs and lows of language and learning. All of these are possible through the kind of 'experiment' engaged in here. 


\section{References}

Appel, J. (1995). Diary of a language teacher. Oxford: Heinemann English Language Teaching.

Bailey, K. (1991). Diary studies of classroom language learning: The doubting game and the believing game. In E. Sadtono (Ed.), Language acquisition and the second/foreign language classroom (pp.60-102). Singapore: SEAMEO Regional language Centre (Anthology Series 28).

http://www.relc.org.sg/biblio.htm

Bailey, K., Curtis, A. \& Nunan, D. (1998). Undeniable insights: The collaborative use of three professional development practices. TESOL Quarterly, 32(3), 546-556.

Bailey, K., Curtis, A. \& Nunan, D. (2001). Pursuing professional development: The self as source. Boston: Heinle \& Heinle.

Birch, G. (1992). Language learning case study approach to second language teacher education. In J. Flowerdew, M.N. Brock, and S. Hsia (Eds.), Perspectives on second language teacher education (pp.283-294). Hong Kong: City Polytechnic of Hong Kong.

Curtis, A. (1999). Re-visioning our roles: Teachers as experts, researchers and reflective practitioners. ThaiTESOL Bulletin, 12(2), 24-32.

http://www.thaitesol.org/bulletin/index.html

Larsen-Freeman, D. (1983). Training teachers or educating a teacher. In J.E. Alatis, H.H. Stern, and P. Strevens, Georgetown University Round Table on language and linguistics: Applied linguistics and preparation of second language teachers: Towards a rationale (pp.264-274). Washington, D.C: Georgetown University Press.

Latulippe, L. (1999). Lessons learned from being a student again (Part 1). TESOL Matters, 9(1), 18. http://www.tesol.org/pubs/articles/index.html

Lowe, T. (1987). An experiment in role-reversal: Teachers as language learners. English Language Teaching Journal, 42(2), 89-96.

Morrison, T. (1993). Jazz. London: Picador. http://www.az.com/ andrade/morrison/jazz.html

Nunan, D. (1994). Research methods in language learning. New York: Cambridge University Press

Sumara, D. (1999). Creating interpretative possibilities with literature in the teacher education classroom. Language and Literacy, 1(2).

http://educ.queensu.ca/ landl/papers/classroom.htm 
Instructional Sports Skills, Fall \& Winter 2000-2001, Queen's University School of Physical and Health Education)

www.phe.queensu.ca/athletics/recreation/iss/issprograms/html

Paley, V. G. (1997). Talking to myself in a daily journal: Reflections of a kindergarten teacher. In C.P. Casanave and S.R. Schecter (Eds.), On becoming a language educator (pp.115-122). Mahwah, NJ: Lawrence Erlbaum.

Palmer, G. (1992). The practical feasibility of diary studies for INSET. European Journal of Teacher Education, 15(3), 239-254.

http://www.atee.org/htm/ejte/ejte.html

van Lier, L. (1988). The classroom and the language learner: Ethnography and second language classroom research. New York: Longman.

http://maxkade.miis.edu/Faculty_Pages/lvanlier/ecolang.html

Wong, S. (1994). Dialogic approaches to teacher research: Lessening the tension. TESOL Journal, 4(1), 11-13.

Woods, D. (1989). Studying ESL teachers' decision-making: rationale, methodological issues and initial results. Carleton Papers in Applied Language Studies, 6, 107-123. 